\title{
Thoughts on Accelerating the Development of China's Service Trade Issues
}

\author{
Xingang Song \\ School of Economics and Management, Huaiyin Institute of Technology, Huaian, China \\ Email: hyjhys@163.com
}

Received July 2014

\begin{abstract}
With the globalization of the world economy and the integration of development, trade in services has become an important driving force and source of the current international economic and trade growth. Since joining WTO in 2001, China's service trade opening steadily expanded, the status of service trade in the foreign trade of the gradual increase in the Chinese. Although China's service trade has a rapid development, from an overall point of view, the development still remain relatively backward with low level of opening. What's more, compared with the world service trade power, there is a very big disparity between them. This paper expounds the present situation of the development of service trade in China, analyzes the existing problems, and puts forward some countermeasures and suggestions to promote China's service trade development.
\end{abstract}

\section{Keywords}

Trade in Services, Problems, Suggestions, Opening up

\section{Introduction}

The service trade of our country started in twentieth Century 80 years, it's late but develops quickly. The service trade not only continues to expand the scale, transportation, communication, finance, insurance and services import and export, deepen economy and trade relations with trading partners, but also introduces technology, foreign advanced management experience and methods, by which to promote China's economic development.. China's service trade develops rapidly, but from an overall point of view, it's still on initial stage and a certain gap still exists compared with the world service trade power. Therefore, enhancing the competitiveness of trade in services, and fundamentally accelerating the opening of service trade in China has become a pressing matter of the moment for the development of foreign trade. Speeding up the service trade of our country open to the outside world, to further adjust the foreign trade import and export structure, and promote the optimization and upgrading of industrial structure, has important theoretical and practical significance for the development of service trade in china.

\section{The Development of China's Service Trade}

\subsection{The Strong Development Momentum of China's Service Trade}

Service trade is the sign of the progress in industry, China's accession to the liberalization of trade in services 
has become an irreversible trend. Although the service trade of our country started relatively late, the development trend is strong. From the opening degree, the opening of the service industry has been covered by the 10 of 12 kinds and 100 involving a total of 160 small classes of general agreement on trade in services. At present, 100 service trade departments including banks, telecommunications, securities, insurance and distribution, has been fully open to foreign investment, accounting for $62.5 \%$ of the total service sector. The open degree of service industry has been close to the level of developed countries [1].

\subsection{Service Trade Continues to Expand the Scale}

With the adjustment of industrial structure and the acceleration of the process of service trade market to the outside world, China's service trade scale continues to expand and improve, showing great leap forward growth. China's service trade import and export volume rose from \$ 4.4 billion in 1982 to $\$ 3044.5$ billion in 2008, 26 years increased by nearly 69 times. In 2013 China service trade import and export $\$ 5396.4$ billion, growth of $14.7 \%$ over the previous year, the proportion of the total foreign trade of $11.5 \%$, continue to top the forefront of the world. In 2012, China's service trade import and export volume ranked third in the world, second only to America and Germany; export ranking fifth in the world (the first four are USA, Britain, Germany, France); imports ranking third in the world (top two for American and Germany).

\subsection{Service Trade, Investment and Outsourcing Initially Formed Integration Pattern}

Since 90's in last century, with the globalization of service industry, the continuous expansion of China's opening up of the service industry, actively introduce service industry investment. In 2011, the proportion of service industry investment for the first time exceeded the manufacturing industry investment accounted for the proportion of $47.2 \%$. The rapid development of international service outsourcing is an important symbol of services globalization. According to the statistics of the Ministry of commerce service trade department, in 2013 Chinese signed undertaking international service outsourcing contract amount of $\$ 623.4$ billion, an increase of 35 of $42.2 \%$; implementation of the amount of $\$ 454.1$ billion, an increase of $35 \%$.

Table 1. In 1997-2012 China import and export services world rankings.

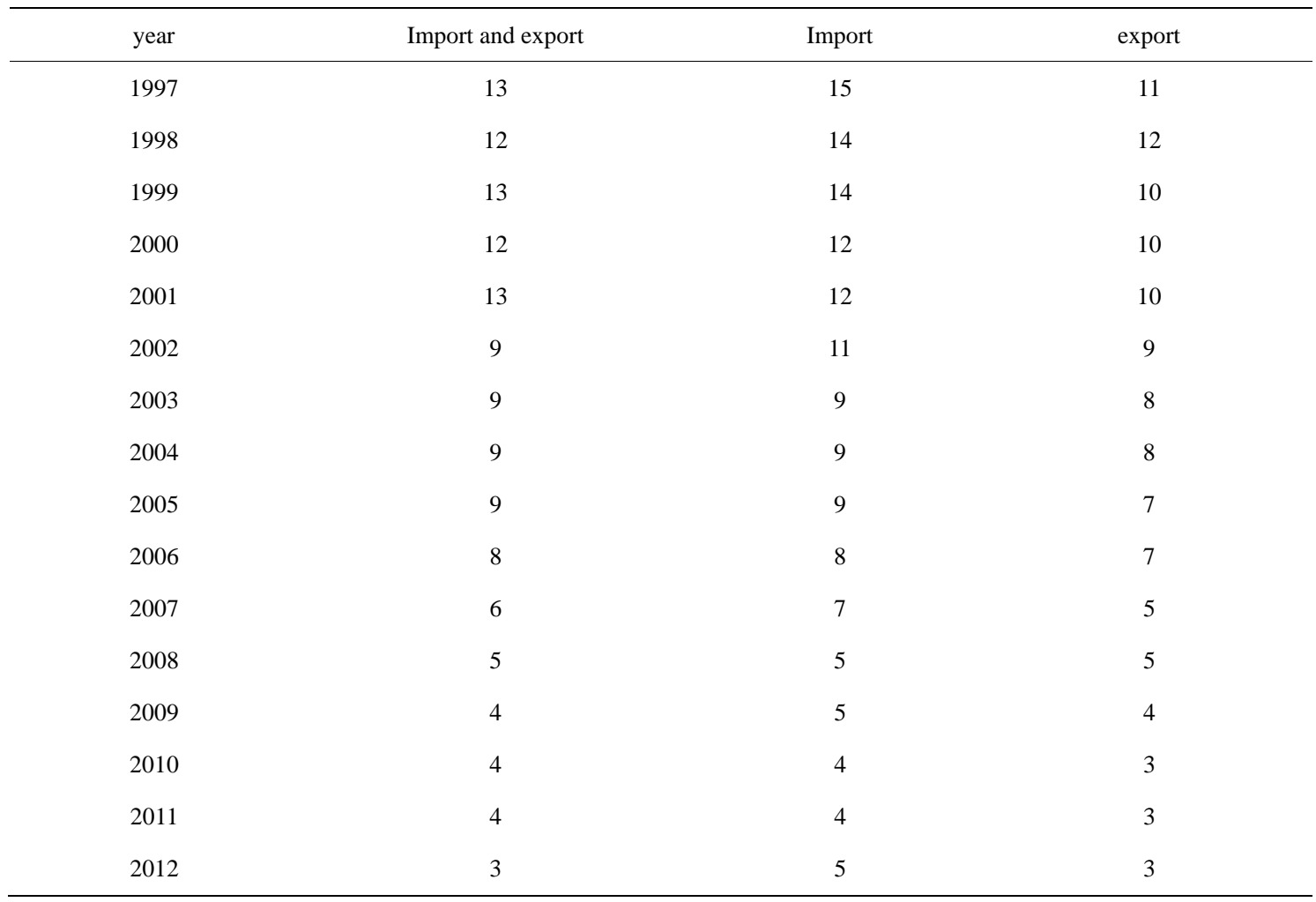




\section{Analysis of the Problems of China's Service Trade Development}

Although service trade development achieve sustained, stable, and healthy, in the aspects of China's economic growth, expanding consumption and easing the employment made outstanding contributions. However, since the starting point of China's service trade is low, with thin foundation and lacking a strong industrial base to support, there are still many gaps and deficiencies in the structure of exports, regional development, etc. At present there exist the following problems in the development of China's service trade.

\subsection{Service Trade Development Is Not Balanced, There Are Large Regional Differences}

At present Chinese service trade export market mainly concentrated in Hongkong, America etc; in the domestic, export trade in services area mainly concentrated in the developed area of Shanghai, Beijing, Zhejiang, Jiangsu, Guangdong and other eastern developed region. The Eastern region has obvious advantages over the inland areas in areas such as transport, computers, insurance, consulting services, information services and advertising In 2010, $75 \%$ of the insurance services, financial services, exclusive rights to use and license as well as the information and computer services import and export concentrated in Beijing, Shanghai and Guangdong three; 91\% service trade concentrated in the eastern 11 provinces, including Beijing, Shanghai and Guangdong accounted for 65\%; and the central and western regions together accounted for only $9 \%$. The unbalanced development of service trade projects and regional distribution restricts the overall level of development of Chinese service trade. At the same time, because the degree of diversification development of trade in services is not enough, which led directly to that the Chinese service trade impact resistant ability is poor and susceptible to the effects of fluctuations in domestic and international situation [2].

\subsection{The Status of Services Trade in Foreign Trade Is Not High, the Development Is Lagging}

China's service trade scale and strength is relatively low, in the foreign trade position far behind the trade in goods. As of the first half of 2010, the goods trade and service trade import and export volume ratio was 8.5:1, while world trade in goods and services trade import and export volume ratio is 2.2:1, which shows that the matching degree Chinese services trade and goods trade is much lower than the world level. China's service trade exports is at a disadvantage. Service trade export comparative advantage is not than the export of goods. China is a net importer of trade in services, and the service trade deficit is widening compared with goods trade, despite the higher growth rate, the absolute amount of service trade of our country is still low. [3] In 2012 Chinese share in global trade in services proportion is $5.6 \%$, only about half of the trade in goods.

The development of domestic service industry is the foundation of service trade, which determines the overall international competitiveness of service trade. The low level of productivity of the domestic service industry restricted the development of foreign trade in services. The service industry accounted for the proportion of GDP, the world average level of $60 \%$, the level of the developed countries in general more than $65 \%$, America even as high as $85 \%$, the average level of developing countries has reached $48 \%$, while China's service industry accounted for the proportion of GDP is not only lower than the developed countries, the average level is lower than the developing countries, and even lower than the average level of 36\% of low-income countries, remained at about 33\%. Thus, although in recent years, China’s service trade development is rapid, but relatively lag.

\subsection{Irrational Structure of Services Trade Exports}

At present, China's trade in services is still mainly focused on tourism, transportation, construction and other traditional services, and the largest in the global trade finance, insurance, communication services, such as technology-intensive and knowledge-intensive service industries, still relatively backward. In 2011, for example, accounted for the largest proportion of trade in services exports is tourism, accounting for 26.6\%; followed by transportation, accounting for $19.5 \%$. The proportion of financial services was $0.5 \%$, communications $0.9 \%$ share of lower proprietary rights royalties and license fees, only $0.4 \%$.

In the export of service trade, the export proportion of transportation and tourism of traditional service trade was on a downward trend, fell from $66 \%$ in 2000 to $46.2 \%$ in 2011 ; but the proportion of exports of five types of emerging service industry such as communication, finance and insurance increased from $6.5 \%$ in 2000 to $10.2 \%$ 
in 2011. Overall, the export structure of trade in services is gradually optimized, but still in the traditional export-oriented trade in services, and the export share of emerging trade in services is small [4].

\subsection{The Overall Level of Service Outsourcing Is Low}

The current development of China's service outsourcing in general is smaller and lack of market development. The Competitiveness of service outsourcing enterprises is not strong. Enterprises scale is generally smaller and $\mathrm{R} \& \mathrm{D}$ ability is low. It is lack of independent products, core technology, leading enterprises. The majority of business is in the low-end outsourcing industry chain, to undertake large scale international outsourcing projects. The proportion of service outsourcing in the trade in services is relatively low, mainly in such as Shenzhen, Shanghai, Dalian and other small parts.

\section{Policy Suggestions and Measures to Speed up the Development of China's Service Trade}

\subsection{Strengthen the Coordinated Development of Regional Service Trade}

The eastern area has the advantages of knowledge, capital and technology while the central and western regions has the advantage of human resources. Through scientific and rational planning and implementing the difference strategy, it can give full play to comparative advantage in service trade development all over the region. The rapid development of trade in services sectors and regions fully play the leading role in the development of trade in services, it will help to achieve positive interaction between the East and Midwest complementary advantages and distinctive features, to better promote the overall development of China's trade in services. Giving full play to the role of local government, the expanding trade in services exports mainly operated by state governments in American. Every state has enacted service trade strategy. Trade in services has reached a considerable level in Beijing, Jiangsu, Shanghai, Guangdong and other places. It should establish the service trade demonstration area in the more developed the service trade area. At the same time in the service trade in key areas, it should identify and support a number of key enterprises or enterprise groups [5].

\subsection{To Expand the Key Industry Export of Services Trade and Enhance the Level of Opening up of Service Trade}

China should encourage exports in key areas of trade in services in order to improve competitiveness of. trade in services. Tourism is the first large department China services export. Although in recent years the tourism industry export growth is slow, but it occupies the entire service trade export 39.64\%, so it will affect the situation as a whole. Building services trade of our country is the export department with traditional advantage. China should focus on cultivating computer information, culture, transport, patent license, financial insurance and other emerging service trade export. China should develop these industries development strategy. We should pay special attention to audio and video, sports, consulting, education, distribution service and other departments, although their current export amount is not large, they have not fast growth, their strength is not strong, but in the long run, these industries need the support and development.

With the arrival of China's accession to the WTO transition period, the service sector is also facing new external environment. Improve operational service levels, led and promote the domestic service industry. To accelerate our services "go out" and actively fight to make new breakthroughs of foreign investment in transportation, distribution, finance, education, culture, tourism and other areas of radio and television [6].

\subsection{Pay Attention to the Accumulation of Human Capital of Service Trade}

Service industry is a knowledge intensive industry. Many emerging service industry must rely on the people's intelligence work to complete, and workers with specialized knowledge and skills. If service providers do not possess the technical knowledge required, it is impossible to provide valuable, especially for high value added services. Therefore, China government should increase input in education, encourage innovation in education, to handle the relationship between formal education and non formal education, social investment and government education investment combination, through increasing investment in education to accumulate human capital. Improve the human capital quality of service is help to gradually optimized export trade of services structure. 


\subsection{Service Outsourcing as the Point of Growth, Vigorously Develop the Offshore Outsourcing}

Service outsourcing is the effective way to the development of China's capital and technology intensive service trade. International service outsourcing business can improve not only the contracting enterprise competitiveness, but also China's service trade. In 2012, China emerged as the world's second largest country to undertake service outsourcing, but at the same time, many enterprises of our country were still in service outsourcing value chain downstream. We should seize the opportunity of the transfer of industries, and the government should improve the policy support and management mechanism of service outsourcing. Vigorously develop the offshore outsourcing, increase the financial insurance, the information technology service outsourcing, and we will gradually move to upstream of service industry chain. By undertaking service outsourcing, we will improve position in the international division of labor in the trade of service and upgrade from comparative advantage to competitive advantage.

\section{References}

[1] Meng, J.G. (2010) Current Status and Development of China’s Service Trade. Journal of Commercial Time, 22, 48-49.

[2] Yao, X., Li, G. and Gao, W. (2010) The 30 Years of Reform and Opening up The Development and Problems of China Service Trade. Journal of International Trade Forum, 3, 36-39.

[3] Zhang, L. (2011) Twelfth Five Year Plan, Period of International Service Trade Development Trend and Countermeasure of Our Country. Journal of International Trade, 1, 24-28.

[4] Wang, C.R. and Chu J.Y. (2013) The Transformation of China’s Service Trade Growth Mode. Journal of Globalization, 8, 74-84.

[5] Ling, H.Z. and Wang Y. (2010) Influencing Factors Analysis of Service Outsourcing in China. Journal of International Economics and Trade Research, 2, 68-72.

[6] Lei, Y.W. (2010) Strategic Measures to Accelerate the Development of China's Service Trade. Journal of North China Electric Power University (Social Science Edition), 3, 51-54. 